\title{
Predictive Value of Ureteral Jet Dynamics to Differentiate Postrenal Obstruction After Renal Transplantation: A Prospective Cohort Study
}

\author{
Renal Transplantasyon Sonrası Postrenal Obstrüksiyonu Ayırmak için Üreteral Jet \\ Dinamiklerinin Öngörü Değeri: Bir Prospektif Kohort Çalışma
}

\author{
(1) Serdar Çelik1, (1) Türker Acar2, (1) Cenk Şimşek33, (1) Arda Yeşilova1, (1) Ibrahim Halil Bozkurt'1, (1) Yusuf Kadir Topçu1, \\ (1) Ertuğrul Şefik1, (1) İsmail Basmacı1 , (1) İsmail Can Tercan³, (1) Serkan Yarımoğlu1', (1) Tansu Değirmenci1, (1) Adam Uslu3 \\ 1 University of Health Sciences Turkiye, İzmir Bozyaka Training and Research Hospital, Clinic of Urology, Izmir, Turkiye \\ 2 University of Health Sciences Turkiye, Izmir Bozyaka Training and Research Hospital, Clinic of Radiology, Izmir, Turkiye \\ 3 University of Health Sciences Turkiye, İzmir Bozyaka Training and Research Hospital, Clinic of General Surgery, Division of Transplantation, Izmir, Turkiye
}

\section{What's known on the subject? and What does the study add?}

In the patients with pelvicalyceal system dilation (PCSD) after renal transplantation (RTx), to differentiate postrenal obstruction from other renal and prerenal reasons, the measurements of ureteral jet dynamics with Doppler ultrasonography (D-US) provide important information to illuminate these suspected situations. Also, the evaluation of ureteral jet dynamics before dilation develops can provide useful information for the management of RTx patients.

\begin{abstract}
Objective: This study aimed to prospectively investigate the predictive value of ureteral jet dynamics measured by Doppler ultrasonography (D-US) to differentiate postrenal obstruction from other reasons after double-J stent (DJS) removal in patients who underwent renal transplantation (RTx) due to chronic renal failure.

Materials and Methods: Patients who underwent RTx between 2017 and 2018 were prospectively evaluated. After RTx, D-US was performed on all patients following DJS removal. Renal Artery Resistive index (RA-Ri), renal pelvis anterior-posterior diameter (RP-APD), pelvicalyceal system dilation (PCSD), and ureteral jet flow dynamics [maximum (JETmax) and average velocity (JETave)] were measured by D-US. Patients' demographics, estimated glomerular filtration rate (eGFR), acute rejection, and hemodialysis (HD) time were investigated. Patients were divided into two groups as patients without PCSD (group 1) and patients with PCSD during follow-up (group 2). In addition, group 2 was also divided into two subgroups as patients with postrenal obstruction (group 2a) and without postrenal obstruction (group 2b). All values were compared between the groups.

Results: A total of 28 patients were evaluated in the study. HD time and RP-APD were significantly higher in group 2 than in group 1 ( $<<0.05$ ). Ureteral jet dynamics between the groups were comparable. In group 2, RA-Ri and RP-APD were comparable, but JETave and JETmax were significantly lower in group 2a.

Conclusion: In patients who underwent RTx with PCSD (especially dilation with suspected acute rejection and low eGFR) after DJS removal, investigation of ureteral jet flow dynamics can provide important information that can help determine and differentiate postrenal obstruction. Keywords: Renal transplantation, Pelvicalyceal dilation, Postrenal obstruction, Ureteral stricture, Ureteral jet dynamics
\end{abstract}

Öz

Amaç: Bu çalışmada kronik böbrek yetmezliği nedeniyle renal transplantasyon (RTx) uygulanan hastalarda double J-stent (DJS) çekildikten sonra postrenal obstrüksiyonu diğer nedenlerden ayırmak için Doppler ultrasonografi (D-US) ile ölçülen üreter jet dinamiklerinin öngörü değerini prospektif olarak araştırmayı amaçladık.

Gereç ve Yöntem: RTx uygulanan hastalar 2017-2018 yılları arasında prospektif olarak değerlendirildi. RTx sonrası DJS çekildikten sonra tüm hastalara D-US uygulandı. D-US ile Renal Arter Rezistif indeksi (RA-Ri), renal pelvis ön-arka çapı (RP-APÇ), pelvikalisiyel sistem dilatasyonu (PKSD) ve üreteral jet akım dinamikleri (maksimum ve ortalama hız; JETmax ve JETave) ölçüldü. Ayrıca çalışmada hastaların demografik özellikleri, tahmini

Correspondence: Serdar Çelik MD, University of Health Sciences Turkiye, İzmir Bozyaka Training and Research Hospital, Clinic of Urology, İzmir, Turkiye Phone: +90 5057019631 E-mail: serdarcelik84@hotmail.com ORCID-ID: orcid.org/0000-0003-0939-9989

Received: 09.04.2020

Accepted: 04.05.2020

Cite this article as: Çelik S, Acar T, Simşek C, Yeşilova A, Bozkurt ï, Topçu YK, Şefik E, Basmacı I, Tercan í, Yarımoğlu S, Değirmenci T, Uslu A. Predictive Value of Ureteral Jet Dynamics to Differentiate Postrenal Obstruction After Renal Transplantation: A Prospective Cohort Study. J Urol Surg 2020;7(4):302-308.

oCopyright 2020 by the Association of Urological Surgery / Journal of Urological Surgery published by Galenos Publishing House. 
glomerüler filtrasyon hızı (eGFR), akut rejeksiyon ve hemodiyaliz (HD) süresi araştıııldı. Hastalar takip sırasında PKSD'si olmayan hastalar (grup 1) ve PKSD'si olan hastalar (grup 2) diye iki gruba ayrıldı. Ayrıca grup 2, postrenal obstrüksiyonu olan (grup 2a) ve postrenal obstrüksiyonu olmayan (grup 2b) olmak üzere iki alt gruba ayrıldı. Tüm veriler gruplar arasında karşılaştırıldı.

Bulgular: Çalışmada toplam 28 hasta değerlendirildi. HD süresi ve RP-APÇ grup 2'de anlamlı olarak daha yüksekti $(p<0,05)$. Üreter jet dinamikleri gruplar arasında benzerdi. Grup 2 değerlendirildiğinde RA-Ri ve RP-APÇ gruplar arasında benzerken, JETave ve JETmax değerleri grup 2a'da anlamlı olarak daha düşük saptandı.

Sonuç: DJS çekildikten sonra PKSD saptanan RTx hastalarında (özellikle akut rejeksiyon ve düşük eGFR seviyesi olan dilate hastalarda), üreteral jet akım dinamiklerinin araştırılması postrenal obstrüksiyonu belirlemek ve ayırt etmek için önemli bilgiler sağlayabilir.

Anahtar Kelimeler: Renal transplantasyon, Pelvikalisiyel sistem dilatasyonu, Postrenal obstrüksiyon, Üreter darlığı, Üreteral jet dinamikleri

\section{Introduction}

The global prevalence of chronic renal failure (CRF) ranges from $11 \%$ to $13 \%$ (1). The gold standard treatment for endstage kidney disease (EKD) is renal transplantation (RTx), which is used for primary patients or follow-up patients in the routine hemodialysis (HD) program (2). After RTx, urological complications such as postrenal obstruction according to stricture or stenosis of the ureterovesical anastomosis can cause significant morbidity for these patients. The incidence of urological complications ranges from $2 \%$ to $13 \%$ after RTx (3). The occurrence of ureteral stricture, which is one of these complications, varies from $0.6 \%$ to $10.5 \%$ (4). Ureteral stricture can present with postrenal obstruction findings such as lack of pain, pelvicalyceal system dilation (PCSD) or hydronephrosis with increasing serum creatinine level, and oliguria (5). Therefore, in RTx patients, close follow-up with ultrasonography (US), serum creatinine or estimated glomerular filtration rate (eGFR) level, and urine amount is needed. A previous study preferred Doppler US (D-US), which is non-invasive and easily accessible method, to examine ureteral jet phenomenon, as it can show the peristaltic activity of the pelvic-ureteric system essential for the diagnosis of postrenal obstruction (6).

Ureteral jet dynamics measured by D-US was evaluated to detect ureteral stone obstruction and nonobstructive kidney stone formation in patients with upper urinary tract stone disease (7-10). However, ureteral jet dynamics was not assessed for evaluation of PCSD or postrenal obstruction in RTx patients.

Therefore, this prospective study aimed to investigate the predictive value of ureteral jet dynamics of a patient cohort to differentiate postrenal obstruction due to other renal and prerenal reasons after double-J stent (DJS) removal in patients who underwent RTx, especially RTx with PCSD.

\section{Materials and Methods}

After ethical approval from the local ethics committee (ethical protocol number: 1/21.02.2018) and informed consent forms were obtained, patients with CRF/EKD who underwent RTx in our tertiary hospital between November 2017 and June 2018 were prospectively evaluated. Patients' characteristics [age, gender, and body mass index (BMI)], HD time, and basal eGFR level were noted before the RTx. Donor type (cadaver or live), RTx side (right iliac fossa or left iliac fossa), RTx operation time, and type of ureterovesical anastomosis (all patients underwent Lich-Gregoir technique in our hospital) were also noted.

During the RTx procedure, for arterial anastomosis, end-to-side anastomosis of the donor renal artery to the recipient external iliac artery or end-to-end anastomosis to the recipient internal iliac artery was performed for all cases. For ureterovesical anastomosis, the Lich-Gregoir anastomosis technique was performed for all cases that include some surgical steps. The anterolateral portion of the bladder was incised through the seromuscular layer. The distal posterior end of the donor ureter was spatulated, and the full thickness of the free edge of the ureter was watertight sewn to the bladder mucosa. Then, the seromuscular layer was closed over the ureter by creating a submucosal tunnel of 2-3 cm (11).

On follow-up, DJS were removed with 17-fr flexible cystoscopy under local anesthesia approximately 4 weeks after RTx. In addition, after DJS removal, eGFR and PCSD presence in the transplanted kidney were also evaluated with renal US. PCSD was present if the renal pelvis anterior-posterior diameter (RPAPD) was $>10 \mathrm{~mm}$. At approximately 6 weeks after DJS removal, D-US was used to measure RP-APD, Renal Artery Resistive index (RA-Ri), and ureteral jet dynamics (maximum rate, average rate, resistive index, and wave form pattern of ureteral jet flow: JETmax, JETave, JET-Ri, and JETpattern, respectively) $(9,10,12,13)$. It was also used to check the presence of PCSD. Enrolled patients were evaluated by an experienced radiologist (TA) who performed blind D-US examination. D-US was performed using 3-5 MHz convex probe after oral hydration with $500-750 \mathrm{~mL}$ of water (Philips HDI 5000; Bothell, WA). During the evaluation, patients were placed in the supine position with full urinary bladder. All abovementioned parameters were measured with angle correction on color D-US.

Moreover, acute rejection and urological complications [urine leakage, lymphocele, ureteral stricture or stenosis, vesicoureteral reflux (VUR), and urolithiasis] were noted during follow-up. 
Patients were divided into two groups: patients without PCSD (group 1) and patients with PCSD during follow-up (group 2). In addition, patients with PCSD (group 2) were divided into two subgroups: patients with postrenal obstruction (PCSD and postrenal obstruction-positive patients, group 2a) and without postrenal obstruction (PCSD positive but postrenal obstruction negative, nonobstructive patients, group 2b). All values were compared between the groups. The obstructive and nonobstructive dilation status of group 2 was assessed by magnetic resonance urography without any contrast (MR-U). Moreover, the nonobstructive dilation status of group $2 b$ was controlled with US at the sixth month after RTx. Secondary interventions were also noted during follow-up.

\section{Statistical Analysis}

Data were analyzed using the Statistical Package for Social Sciences, version 20.0 (SPSS, Chicago, III) software program. In the group and subgroup analysis, Mann-Whitney $\mathrm{U}$ test and chi-square test (Yates' chi-square test and Fisher's Exact test) analyses were used. Data are presented as mean \pm standard deviation. However, $p$ values are given according to medians. Statistical significance was defined as $p<0.05$.

\section{Results}

A total of 31 patients were investigated in the study. Three of them were excluded for various reasons (ureteral jet dynamics could not be measured in one patient and follow-up data were missed in two patients), and 28 patients were finally evaluated in the study. For all patients, the mean age was $42.7 \pm 13.6$ (22$67)$ years, the mean BMI was $23 \pm 3.7(17.5-33.8) \mathrm{kg} / \mathrm{m}^{2}, 20$ were males, and 8 were females. The mean HD time was $52 \pm 50.7$ (0-192) months, and the basal eGFR was $12 \pm 6(5.3-27.8) \mathrm{mL} /$ $\min / 1.73 \mathrm{~m}^{2}$ before RTx.

As for the donor type, 16 patients had cadaver donors and 12 had live donors. The RTx side was the right iliac fossa in 20 and left iliac fossa in 8 patients. The mean RTx operation time was $203 \pm 17.9(180-240) \mathrm{min}$. All ureterovesical anastomoses used the Lich-Gregoir technique of extravesical ureteroneocystostomy to connect the donor ureter into the recipient bladder during RTx. The mean eGFR was $56.9 \pm 14(20-77) \mathrm{mL} / \mathrm{min} / 1.73 \mathrm{~m}^{2}$ after DJS removal. On follow-up, urine leakage, VUR, or urolithiasis was not observed. Lymphocele was detected in four patients $(14.3 \%)$, and all of them were treated with percutaneous drainage. Three patients (10.7\%) had postrenal obstruction and ureteral stricture (group 2a) and were treated with immediate DJS placement after detection by creatinine test, D-US, and MR-U. Two of these patients underwent ureterovesical anastomosis revision. One of them is temporarily on followup with DJS every year. Three patients were found to have non-obstructive dilation in D-US and MR-U evaluations, and these non-obstructive dilations regressed at the sixth month of US evaluation. Immunosuppressive and immunomodulatory drugs, such as prednisolone and mycophenolate mofetil or mycophenolic acid and everolimus or tacrolimus, were given to all patients as protection against kidney rejection. Nevertheless, acute kidney rejection developed in six cases (T-cell-mediated rejection in three and antibody-mediated rejection in three cases), and borderline changes were found in four cases. These patients are still on follow-up. In addition, no patients had BK viremia.

In the evaluation of groups 1 and 2, the time to D-US after DJS removal was $41.3 \pm 8.7$ (23-58) days for group 1 and $37.7 \pm 19.9$ (11-58) days for group 2 ( $p>0.05)$. Comparison results of the groups are shown in Table 1. Interestingly, the HD time was significantly higher in group 2 than in group 1 [110.3 \pm 63 (2-192) months vs $36.1 \pm 33.4$ (0-84) months, respectively, $\mathrm{p}=0.006]$. In the D-US evaluation, RP-APD was higher in group 2 than in group 1. However, other parameters of D-US were not significantly different between the groups.

In the subgroup evaluation of group 2, the mean time to D-US after DJS removal was $23 \pm 15.9$ (11-41) days for group 2a and $52.3 \pm 9.8(41-58)$ days for group $2 b(p>0.05)$. Data analysis results between the groups are shown in Table 2. The RTx operation time was shorter in group 2a than in $2 b[193.3 \pm 11.5(180-200)$ $\min$ vs $216.7 \pm 5.8(210-220) \mathrm{min}$, respectively, $p=0.043]$. Acute rejection rates and eGFR after DJS removal in the groups were comparable. Interestingly, the HD time was higher in group 2a than in group $2 b$; however, statistical significance was not found. In the D-US evaluation, RA-Ri and RP-APD values were comparable between the groups, but JETave $[7.8 \pm 3.4(5.8-11.7)$ vs $21.5 \pm 4(17.3-25.3)$, respectively, $\mathrm{p}=0.011]$ and JETmax [13.8 \pm 5.3 (7.8-17.7) vs $28.5 \pm 4.4$ (23.6-32), respectively, $p=0.022$ ] values were significantly lower in group $2 \mathrm{a}$ than in group $2 \mathrm{~b}$.

\section{Discussion}

In summary, RP-APD and HD time were higher in the PCSD group. In the evaluation of the PCSD group, RA-Ri and RP-APD values were similar between the groups, but JETave ( 7.8 vs 21.5 , $\mathrm{p}=0.011$ ) and JETmax ( 13.8 vs $28.5, \mathrm{p}=0.022$ ) were significantly lower in the PCSD and postrenal obstruction group. However, the distribution of JETpattern was similar between the groups.

RTx is the gold standard treatment modality for CKD patients, which is performed as primary or secondary after the HD program (2). In the RTx procedure, the Lich-Gregoir technique (extravesical ureteroneocystostomy technique between the donor ureter and the recipient bladder) is the most commonly used procedure because it reduces overall complications (specifically urine leak, stricture, and postoperative hematuria) 


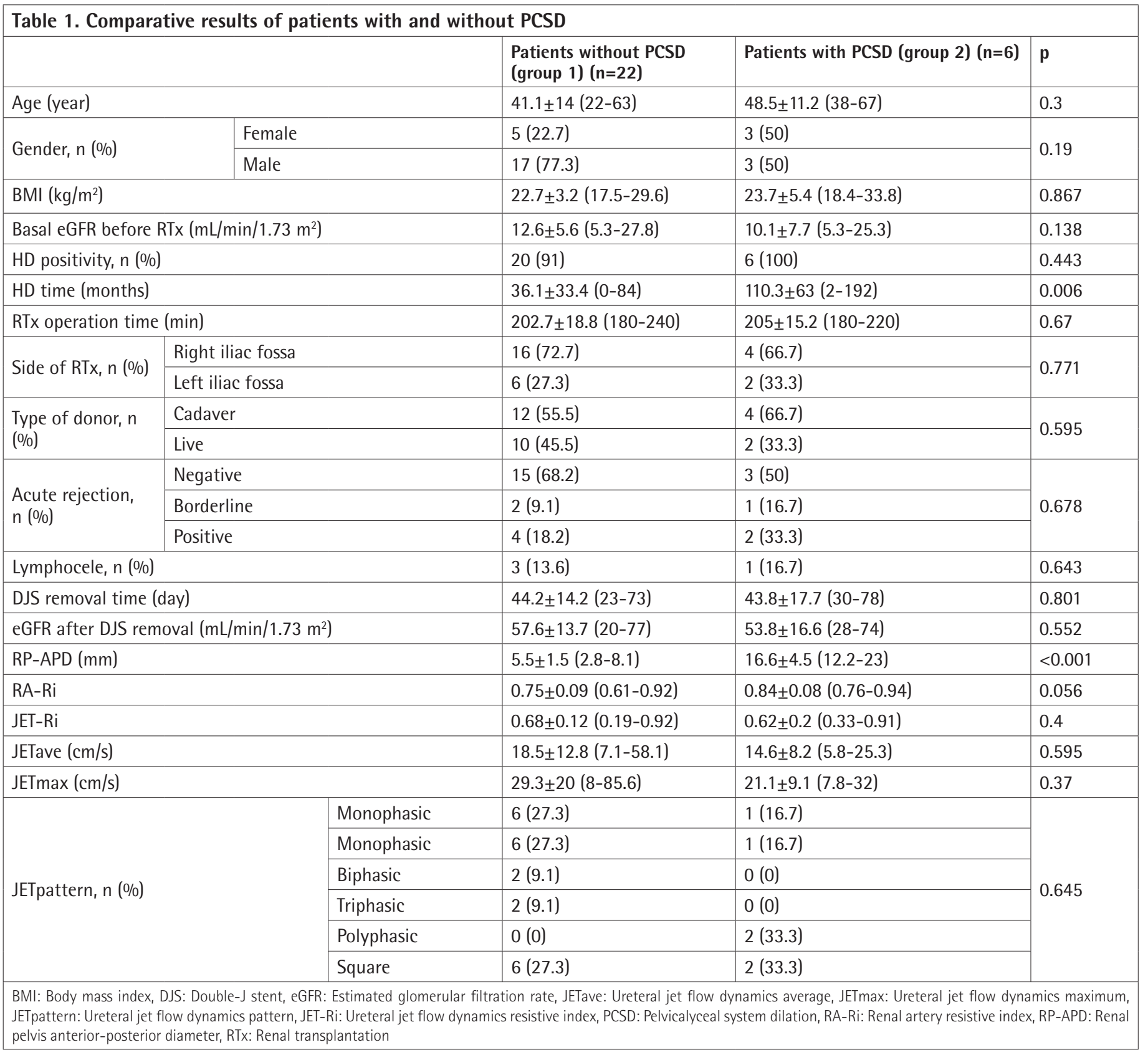

$(11,14)$. In our study, the Lich-Gregoir technique was used for ureterovesical anastomosis.

The incidence of urological complications after RTx ranges from $2 \%$ to $13 \%$ (3). The most common urological complications after RTx are urine leakage, lymphocele, ureteral stricture or stenosis, VUR, and urolithiasis (2,15-21). The most important urological complication is ureteral stricture or stenosis, which is also the most common cause of postrenal obstruction after RTx. The occurrence of ureteral stricture varies from $0.6 \%$ to $10.5 \%$ (4). Postrenal obstruction is commonly accompanied with PCSD/hydronephrosis and increasing serum creatinine levels (5). Therefore, US evaluation of the transplanted kidney is routinely recommended (5). In the management of ureteral strictures, endourological procedures such as DJS placement are commonly used as first-line treatment strategies $(3,5,15)$. After the immediate urinary diversion with DJS, various endourological procedures can be performed such as balloon or fascial dilation and endoureterotomy $(3,5)$. In early follow-up after RTx, urine leakage, VUR, and urolithiasis were not observed. Lymphocele was detected in four patients (14.3\%), and all of them were treated with percutaneous drainage. Three patients (10.7\%) were diagnosed with postrenal obstruction and ureteral stricture. They were treated with immediate DJS placement for early management of postrenal obstruction.

For the evaluation of ureteral jets, some studies reported that at least 30 min of D-US examination is needed to document 


\begin{tabular}{|c|c|c|c|c|}
\hline & & $\begin{array}{l}\text { Patients with PCSD and } \\
\text { postrenal obstruction (group 2a) } \\
(n=3)\end{array}$ & $\begin{array}{l}\text { Patients with PCSD positive but } \\
\text { without postrenal obstruction } \\
\text { (group 2b) }(n=3)\end{array}$ & $\mathbf{p}$ \\
\hline \multicolumn{2}{|l|}{ Age (year) } & $52.7 \pm 14.5(38-67)$ & $44.3 \pm 7.1(38-52)$ & 0.376 \\
\hline Gender, n (\%) & Female & $1(33.3)$ & $2(66.7)$ & 0.414 \\
\hline \multicolumn{2}{|l|}{ BMI $\left(\mathrm{kg} / \mathrm{m}^{2}\right)$} & $22.8 \pm 2(20.6-24.3)$ & $24.6 \pm 8(18.4-33.8)$ & 0.827 \\
\hline \multicolumn{2}{|c|}{ eGFR before $\mathrm{RTx}\left(\mathrm{mL} / \mathrm{min} / 1.73 \mathrm{~m}^{2}\right)$} & $7.4 \pm 2.5(5.3-10.1)$ & $12.8 \pm 10.9(5.6-25.3)$ & 0.827 \\
\hline \multicolumn{2}{|l|}{ HD positivity, n (\%) } & $3(100)$ & $3(100)$ & 1 \\
\hline \multicolumn{2}{|l|}{ HD time (months) } & $136 \pm 50(96-192)$ & $84.7 \pm 73.8(2-144)$ & 0.513 \\
\hline \multicolumn{2}{|c|}{ RTx operation time (minute) } & $193.3 \pm 11.5(180-200)$ & $216.7 \pm 5.8(210-220)$ & 0.043 \\
\hline Donor, n (\%) & Live & 1 (33.3) & $1(33.3)$ & 1 \\
\hline \multirow[t]{3}{*}{ Acute rejection, n (\%) } & Negative & $2(66.7)$ & $1(33.3)$ & \multirow[t]{3}{*}{0.513} \\
\hline & Borderline & $0(0)$ & $1(33.3)$ & \\
\hline & Positive & 1 (33.3) & 1 (33.3) & \\
\hline \multicolumn{2}{|l|}{ Lymphocele, n (\%) } & $0(0)$ & 1 (33.3) & 0.5 \\
\hline \multicolumn{2}{|l|}{ DJS removal time (day) } & $48.7 \pm 25.5(32-78)$ & $39 \pm 8.2(30-46)$ & 0.827 \\
\hline \multicolumn{2}{|c|}{ eGFR after DJS removal $\left(\mathrm{mL} / \mathrm{min} / 1.73 \mathrm{~m}^{2}\right)$} & $43 \pm 21.2(28-58)$ & $61 \pm 11.5(52-74)$ & 0.546 \\
\hline \multicolumn{2}{|l|}{ RP-APD (mm) } & $16.6 \pm 4.6(12.2-21.3)$ & $16.7 \pm 5.5(13-23)$ & 0.827 \\
\hline \multirow{4}{*}{ JETpattern, n (\%) } & Triphasic & $0(0)$ & $0(0)$ & \multirow{4}{*}{0.428} \\
\hline & Polyphasic & $0(0)$ & $0(0)$ & \\
\hline & Square & 1 (33.3) & $1(33.3)$ & \\
\hline & Continuous & $1(33.3)$ & $1(33.3)$ & \\
\hline
\end{tabular}

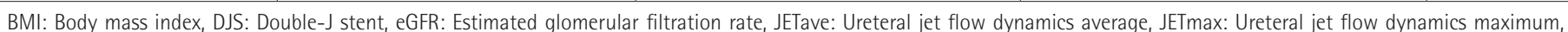

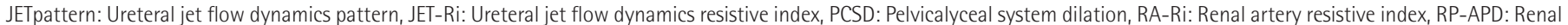
pelvis anterior-posterior diameter, RTx: Renal transplantation

ureteral jet frequency (2-45 min between the urine jets) (22). However, most studies have evaluated patients with D-US for 5-10 min $(7,8,23,24)$. We also examined RTx patients for 10 min of continuous observation with D-US. Therefore, we could not evaluate the ureteral jet frequency in our RTx patients because of the rapid examination. In ureteral jet dynamics, peak velocity (JETmax) and mean velocity (JETave), which are mostly evaluated in previous studies, varied from 16 to $150 \mathrm{~cm} / \mathrm{s}$ for healthy subjects $(12,22,25)$. Recently, ureteral jet dynamics were used in a few studies related to urinary tract stone disease. Some studies reported that lower ureteral jet flow is associated with obstruction on the affected side of patients with ureteral stones $(7,8)$. One study reported that ureteral jets with lower peak flow rate and frequency are associated with ureteral obstruction compared with contralateral healthy ureters. They found that the cut-off point of the ureteral jet peak flow rate was $19.5 \mathrm{~cm} / \mathrm{s}$ between the obstructed and normal ureters to precisely diagnose ureteral obstruction in patients suspected of having urinary stone (7). In another study, the average peak flow rate of the ureteral jet was $17.1 \mathrm{~cm} / \mathrm{s}$ for the affected side and $56 \mathrm{~cm} / \mathrm{s}$ for the unaffected side in patients with unilateral ureteral stones (8). Ureteral jets of transplanted kidneys can be assessed noninvasively and easily using D-US (6). D-US imaging of the ureteral jet dynamics can also be used to exclude ureteral 
obstruction in transplanted kidneys, like the healthy kidneys as mentioned above (6). In our series, the JETmax and JETave of all patients were $27.5 \pm 18.3(7.8-85.6) \mathrm{cm} / \mathrm{s}$ and $17.6 \pm 11.9(5.8-$ $58.1) \mathrm{cm} / \mathrm{s}$, respectively.

The distribution of the ureteral jet wave forms in healthy populations differs from that in RTx patients. In the RTx group, ureteral jet patterns present as $66.1 \%$ monophasic, $23.2 \%$ biphasic, 3.6\% triphasic, $0 \%$ polyphasic, $5.4 \%$ square, and $1.8 \%$ continuous (26). The monophasic wave form is more common in the RTx group (66.1\%) than in the healthy group (for right and left kidney at 2.6\% and 2.5\%, respectively) (26). Moreover, the flow rate and duration of ureteral jets were significantly decreased in the RTx group compared with the healthy group (26). In our study, $28.6 \%$ square and $28.6 \%$ continuous patterns were observed, whereas $25 \%$ of the patients had monophasic ureteral jet pattern.

In our comparative analysis, higher HD time was associated with PCSD. HD time may affect the urine amount before RTx, and this urine amount may affect bladder neuromuscular function and bladder volume. We think that PCSD may be related to neuromuscular dysfunction, urine amount, and HD time. In evaluation of the PCSD group, the measurements of PCSD (RPAPD) were similar between the groups, but ureteral jet flow rates (JETave and JETmax) were significantly lower in PCSD and postrenal obstruction group than in the group without postrenal obstruction. Normally, ureteral jet flow rates decrease after RTx. However, the most important finding of the study is that these flow rates also decrease more than the normal levels for the transplanted kidneys in the presence of ureteral stricture and postrenal obstruction. By contrast, non-obstructive dilations in all three patients regressed at the sixth month of US evaluation. This situation shows that some transient reasons may cause a non-obstructive dilation after RTx in some patients, such as neuromuscular dysfunction and small bladder volume due to long-term HD program and blood clot and edema of the anastomosis.

In light of all results, early diagnosis and early management of ureteral stricture, which is the most important early complication and most common cause of postrenal obstruction after RTx, have crucial roles for kidney preservation in RTx patients. Therefore, D-US evaluation of ureteral jet dynamics after DJS removal may provide important data for early diagnosis of ureteral stricture such as lower JETmax and JETave.

\section{Study Limitations}

This study has some limitations. This study included a small number of patients and did not include measurement of ureteral jet frequency. However, as this is a pilot study, we planned to perform a large cohort study to evaluate RTx patients using D-US measurements.

\section{Conclusion}

In patients with PCSD after RTx and DJS removal (especially, in patients suspected of acute kidney rejection, low eGFR, and concomitant PCSD), to differentiate postrenal obstruction from other renal and prerenal reasons, the measurements of ureteral jet dynamics with D-US can provide important information to illuminate these suspected situations. After DJS removal, in the follow-up of patients with low eGFR or suspected of acute kidney rejection, ureteral jet dynamics (JETave and JETmax) can be evaluated by D-US before dilation develops. However, these findings need to be also supported by larger series.

\section{Ethics}

Ethics Committee Approval: The study were approved by the University of Health Sciences Turkiye, İzmir Bozyaka Training and Research Hospital Clinical Research Ethics Committee (ethical protocol number: 1/21.02.2018).

Informed Consent: Written consent was obtained from all patients.

Peer-review: Externally peer-reviewed.

\section{Authorship Contributions}

Surgical and Medical Practices: S.Ç., C.Ş., I..H.B., A.U., Concept: S.Ç., T.A., C.Ş., Design: S.Ç., T.A., C.Ş., Data Collection or Processing: S.Ç., T.A., C.Ş., A.Y., I.C.T., Analysis or Interpretation: S.Ç., I.H.B., Y.K.T., E.Ş., I.B., S.Y., T.D., A.U., Literature Search: S.Ç., T.A., C.Ş., A.Y., Writing: S.Ç.

Conflict of Interest: No conflict of interest was declared by the authors.

Financial Disclosure: The authors declare that they have no relevant financial.

\section{References}

1. Hill NR, Fatoba ST, Oke JL, Hirst JA, O'Callaghan CA, Lasserson DS, Hobbs FD. Global Prevalence of Chronic Kidney Disease- a Systematic Review and Meta-Analysis. PLoS One 2016;11:e0158765.

2. Breda A, Budde $K$, Figueiredo A, Lledó García E, Olsburgh J, Regele H. EAU Guidelines on Renal Transplantation. 2018. Uroweb. http://uroweb.org/ guideline/renal-transplantation/

3. Bhagat VJ, Gordon RL, Osorio RW, LaBerge JM, Kerlan RK Jr, Melzer JS, Bretan PN, Wilson MW, Ring EJ. Ureteral obstructions and leaks after renal transplantation: Outcome of percutaneous antegrade ureteral stent placement in 44 patients. Radiology 1998;209:159-167.

4. Breda A, Bui MH, Liao JC, Gritsch HA, Schulam PG. Incidence of ureteral strictures after laparoscopic donor nephrectomy. J Urol 2006;176:10651068.

5. Duty BD, Conlin MJ, Fuchs EF, Barry JM. The current role of endourologic management of renal transplantation complications. Adv Urol 2013;2013:246520. 
6. Wiesner W, Wedegaertner U, Stoffel F, Sonnet S, Bongartz G, Steinbrich $W$. Autonomous pelvi-ureteric peristalsis in renal transplants confirmed by color Doppler mapping of the jet phenomenon. Eur Radiol 2001;11:525526 .

7. Jandaghi AB, Falahatkar $S$, Alizadeh A, Kanafi AR, Pourghorban R, Shekarchi B, Zirak AK, Esmaeili S. Assessment of ureterovesical jet dynamics in obstructed ureter by urinary stone with color Doppler and duplex Doppler examinations. Urolithiasis 2013;41:159-163.

8. Ciftci $H$, Cece $H$, Dusak $A$, Savas M, Verit A, Yeni E. Study of the ureterovesical jet flow by means of dupplex Doppler ultrasonography in patients with residual ureteral stone after extracorporeal shock wave lithotripsy. Urol Res 2010;38:47-50.

9. Celik S, Altay C, Bozkurt O, Uz G, Ongun S, Demir O, Secil M, Aslan G. Association between ureteral jet dynamics and nonobstructive kidney stones: a prospective-controlled study. Urology 2014;84:1016-1020.

10. Celik S, Bozkurt O, Altay C, Celebi Celik F, Uz G, Soylu A, Kefi A, Kavukcu $S$, Secil M, Demir O. Evaluation of ureteral jet dynamics in pediatric kidney stone formers: A cross-sectional study. J Pediatr Urol 2016;12:381.e1-385. e5.

11. Alberts VP, Idu MM, Legemate DA, Laguna Pes MP, Minnee RC. Ureterovesical anastomotic techniques for kidney transplantation: a systematic review and meta-analysis. Transpl Int 2014;27:593-605.

12. Leung VY, Chu WC, Yeung CK, Metreweli C. Doppler waveforms of the ureteric jet: an overview and implications for the presence of a functional sphincter at the vesicoureteric junction. Pediatr Radiol 2007;37:417-425.

13. Leung VY, Metreweli $C$, Yeung CK. The ureteric jet doppler waveform as an indicator of vesicoureteric sphincter function in adults and children. An observational study. Ultrasound Med Biol 2002;28:865-872.

14. Slagt IK, Dor FJ, Tran TC, Kimenai HJ, Weimar W, Ijzermans JN, Terkivatan T. A randomized controlled trial comparing intravesical to extravesical ureteroneocystostomy in living donor kidney transplantation recipients. Kidney Int 2014;85:471-477.

15. Sabnis RB, Singh AG, Ganpule AP, Chhabra JS, Tak GR, Shah JH. The development and current status of minimally invasive surgery to manage urological complications after renal transplantation. Indian J Urol 2016;32:186-191.

16. Dominguez J, Clase CM, Mahalati $\mathrm{K}$, MacDonald AS, McAlister VC, Belitsky $\mathrm{P}$, Kiberd $\mathrm{B}$, Lawen JG. Is routine ureteric stenting needed in kidney transplantation? A randomized trial. Transplantation 2000;70:597-601.

17. El-Mekresh M, Osman $Y_{1}$ Ali-El-Dein B, El-Diasty $T_{1}$ Ghoneim MA Urological complications after living-donor renal transplantation. BJU Int 2001;87:295-306.

18. Atray NK, Moore F, Zaman F, Caldito G, Abreo K, Maley W, Zibari GB. Post transplant lymphocele: a single centre experience. Clin Transplant 2004;18 Suppl 12:46-49.

19. Mastrosimone S, Pignata G, Maresca MC, Calconi G, Rabassini A, Butini R, Fandella A, Di Falco G, Chiara G, Caldato C. Clinical significance of vesicoureteral reflux after kidney transplantation. Clin Nephrol 1993;40:3845.

20. Verrier C, Bessede T, Hajj P, Aoubid L, Eschwege P, Benoit G. Decrease in and management of urolithiasis after kidney transplantation. J Urol 2012;187:1651-1655.

21. Challacombe B, Dasgupta P, Tiptaft R, Glass J, Koffman G, Goldsmith D, Khan MS. Multimodal management of urolithiasis in renal transplantation. BJU Int 2005;96:385-389.

22. Cox IH, Erickson SJ, Foley WD, Dewire DM. Ureteric jets: evaluation of normal flow dynamics with color Doppler sonography. AJR Am J Roentgenol 1992;158:1051-1055.

23. Asrat T, Roossin MC, Miller El. Ultrasonographic detection of ureteral jets in normal pregnancy. Am J Obstet Gynecol 1998;178:1194-1198.

24. Burke BJ, Washowich TL. Ureteral jets in normal second and third-trimester pregnancy. J Clin Ultrasound 1998;26:423-426.

25. Matsuda T, Saitoh M. Detection of the urine jet phenomenon using Doppler color Xow mapping. Int J Urol 1995;2:232-234.

26. Leung VY, Metreweli C. Ureteric jet in renal transplantation patient. Ultrasound Med Biol 2002;28:885-888. 